\title{
PERSEPSI NILAI PELANGGAN DAN KEPUASAN DI KLINIK SWASTA “X” DI SURABAYA
}

Perceived customer value and satisfaction in a private clinic " $X$ " in Surabaya

Mohammad Rahman Hakim

Perhimpunan Sarjana Kesehatan Masyarakat Indonesia (Persakmi) Kota Kediri

Email: mrhakim.id@gmail.com

\begin{abstract}
The increasing number of health service industry caused an increase of health service demand. Keeping service quality is a main key to give good service to patient. One of service quality measurement methods is through patient satisfaction measurement. To service quality which given by health service facility this research aim to identify patient satisfaction toward service quality in Clinic " $X$ " in Surabaya. The research has been implemented with cross sectional design using quantitative approach. The research use questionnaire which given to 89 patients. On patient service quality satisfaction, patient satisfaction toward interaction, service environment and outcome quality is in stratified category. Total satisfaction in stratified category too. Perceived customer value is in good category. Satisfaction on aspect interaction quality and outcome quality is significantly related to perceived customer value. Total satisfaction is significantly related too with perceived customer value.
\end{abstract}

Keywords: customer value, quality, satisfaction, service

\section{PENDAHULUAN}

Industri pelayanan kesehatan di Indonesia mengalami peningkatan yang sangat signifikan. Semakin meningkatnya fasilitas pelayanan, membuat masyarakat semakin banyak memiliki alternatif pilihan untuk melakukan akses pelayanan kesehatan. Sebagai penyedia layanan kesehatan, menjaga kualitas pelayanan adalah suatu landasan penting untuk menarik pelanggan dan memanfaatkan pelayanan yang dikelolanya. Untuk mendefinisikan penilaian kualitas pelayanan yang didapatkan dapat menggunakan beberapa metode, salah satunya menggunakan kepuasan pelanggan (Supriyanto and Wulandari, 2011).

Diketahui penilaian kepuasan pada pada sebuah Klinik “X” di Surabaya, di Tahun 2016 tidak mencapai target yang diinginkan. Pencapaian sebesar 3.27 tidak memenuhi dari target yang diinginkan, yakni sebesar 3.34. Pencapaian di Tahun 2016 merupakan pencapaian terendah sepanjang tiga tahun terakhir. Tujuan dari penelitian ini adalah untuk melakukan identifikasi terhadap perceived customer value dan kepuasan terhadap kualitas pelayanan.

\section{PUSTAKA}

\section{Mutu Pelayanan}

Mutu pelayanan merupakan isu stategik bagi setiap organisasi pemasaran, terlepas dari bentuk produk yang dihasilkan. Lewis dan Booms (1983) sebagai pakar yang pertama kali mendefiniskan mutu pelayanan sebagai ukuran seberapa bagus tingkat layanan yang diberikan mampu sesuai dengan ekspetasi pelanggan. Mutu pelayanan bisa diwujudkan melalui pemenuhan kebutuhan dan keinginan pelanggan serta ketepatan penyampaiannya untuk mengimbangi harapan pelanggan.

Penilaian mutu pelayanan akan menjadi landasan dalam membuat kebijakan perbaikan kualitas secara keseluruhan dalam proses bisnis, maka kondisi tertentu sangat diperlukan untuk 
mendukung pengukuran kualitas yang valid (Nasution, 2005).

\section{Perceived customer value (persepsi nilai pelanggan)}

Perceived customer value merupakan suatu dampak yang timbul terhadap terjadinya customer value. Customer value (nilai pelanggan) memberikan manajer memberikan manajer suatu fokus yang menyediakan produk dan jasa pelayanan yang memenuhi kebutuhan pelanggan. Customer value didefinisikan sebagai hasil penjumlahan dari manfaat yang diperoleh dan pengorbanan yang diberikan, yang hasilnya memiliki konseskuensi penggunaan produk atau jasa pelayanan untuk memenuhi kebutuhan dari pelanggan. Sedangakan nilai (value) dapat didefinisikan sebagai rasio antara manfaat yang dirasakan terhadap harga (Tjiptono,1997), dengan perhitungan nilai adalah hasil dari manfaat yang dirasakan dibagi dengan faktor harga.

Definisi lain dari value menurut lqbal (2012) merupakan preferensi yang bersifat relative (komparatif, personal dan situasional) yang memberi ciri pada pengalaman seseorang dalam berinteraksi dengan beberapa objek.

Pemikiran terhadap customer value memiliki variasi yang beragam berkaitan dengan definisi, model, dan konsep yang ditemukan dalam berbagai referensi. Peneliti secara umum mempertimbangkan customer value sebagai gagasan teoritis, subjektif, dan multidimensional yang dinamis dan dipandang secara relatif akan terhadap terjadinya suatu persaingan (Graf and Maas, 2008).

\section{Customer Satisfaction (kepuasan pelanggan)}

Pembeli atau pengguna jasa akan memberikan suatu penilaian terhadap produk atau jasa tersebut dan memberikan perasaan puas atau tidak puas. Satisfaction (kepuasan) menurut Philip Kotler (2008) adalah tingkat keadaan yang dirasakan seseorang yang merupakan hasil dari membandingkan penampilan atau outcome produk yang dirasakan dalam hubungannya dengan harapan seseorang. Kepuasan pelanggan atau kepuasan sepenuhnya menurut (Japanese of Union Scientists and Engineers) JUSE (1987) didefinisikan sebagai mutu besar atau mutu luas (Big Quality atau Broad Quality).

Brady dan Conin (2001) menjelaskan ada tiga faktor yang diamati dalam pembentukan kualitas pelayan. Dimensi kepuasan tersebut menjelaskan bahwa kualitas pelayanan terbentuk dari tiga aspek yaitu Interaction quality, service environment quality, dan outcome quality.

\section{Interaction quality (kualitas interaksi)}

Merupakan bagaimana kualitas yang tercipta antara pasien dengan penyedia layanan kesehatan yang berkaitan dengan personal seperti petugas administrasi, petugas pemeriksaan, dan dokter. Ada tiga aspek yang diperhitungkan dalam dalam interaction quality, yaitu attitude, behavior, dan expertise.

Attitude merupakan sikap yang dimiliki oleh penyedia layanan yang berkaitan dengan penilaian pelanggan. Sikap yang dimaksud meliputi pemenuhan kebutuhan pelanggan oleh petugas, respon petugas dalam menanggapi keluhan yang 
disampaikan, kepedulian petugas, kesopanan petugas saat memberikan pelayanan, dan keramahan petugas.

Behavior pada kualitas interaksi berkaitan erat dengan perilaku petugas saat memberikan pelayanan. Penilaian terhadap perilaku meliputi kecepatan dalam menanggapi respon pelanggan, pemahaman petugas dalam memenuhi kebutuhan, dan keberadaan petugas yang menunjukkan kesiapsiagaan petugas selam jam kerja.

Expertise dalam kualitas interaksi adalah penjabaran dari keahlian yang menunjukkan tingkat profesionalisme petugas terhadap tugas pokok yang dikerjakan dengan tingkat ilmu yang dimiliki. Penilaian keahlian mencakup kemampuan yang dimiliki oleh petugas, konsistensi petugas dalam memberikan pelayanan, serta tidak adanya diskriminasi yang dirasakan oleh pelanggan selama proses pelayanan.

Keahlian pada tenaga medis lebih dapat ditentukan melalui keakuratan diagnosis yang diberikan oleh dokter, penanangan perawatan luka oleh petugas perawat, atau keakuratan hasil dari tenaga laboratorium. Kesesuaian paket pelayanan yang didapatkan dengan apa yang dijanjikan oleh petugas, bisa menjadi salah satu penentu kualitas interaksi.

\section{Service Environment Quality (kualitas lingkungan fisik)}

Merupakan suatu kualitas yang timbul dari pasien atau pelanggan terhadap kondisi lingkungan di tempat pelayanan kesehatan meliputi ambient condition, design, dan social factors. Ambient condition merupakan kondisi lingkungan sekitar, meliputi kelengkapan fasilitas, kesejukan ruangan, pencahayaan ruangan, serta aroma ruangan. Desain fasilitas yang terdapat pada kualitas lingkungan meliputi rancangan bentuk dari fasilitas, pemilihan warna, dan penataan ruangan. Social factors dalam kajian kualitas lingkungan merupakan bagaimana sikap dari orang yang ada di tempat layanan jasa. Penilaian ini bisa dilihat dari kepadatan antrian saat proses pelayanan serta keteraturan.

\section{Outcome quality (kualitas hasil)}

Outcome quality merupakan kualitas yang didapatkan setalah pasien atau pelanggan telah mendapatkan pelayanan dari tempat pelayanan kesehatan. Ada beberapa outcome quality yang bisa dikaji diantaranya waiting time, tangibles, dan valence.

Waiting time merupakan waktu tunggu dari pelanggan dalam melakukan akses pada setiap tahapan pelayanan sesuai dengan kebutuhan pelanggan. Waktu tunggu yang dilihat dalam pelayanan jasa kesehatan berupa waktu tunggu dari mulai masuk hingga proses pendaftaran dan waktu tunggu sampai dengan mendapatkan pelayanan kesehatan oleh tenaga medis berupa dokter maupun perawat. Hal lainnya yang masuk dalam waktu tunggu adalah pada proses pemberian obat. Hal tersebut sangat erat kaitannya dengan pelayanan kesehatan secara menyeluruh.

Tangibles adalah aspek penilaian kualitas lingkungan fisik yang tampak oleh indra penglihatan. $\mathrm{Hal}$ tersebut meliputi kebersihan ruangan, kebersihan terhadap pakaian petugas di tempat 
pelayanan kesehatan, kebersihan peralatan baik pada peralatan medis dan non medis, serta bagaiman perawatan dari pelatan tersebut.

Valence merupakan penjabaran yang didapatkan dari kumulatif pengalaman yang ada pada pelanggan.

\section{METODE}

Penelitian ini merupakan termasuk penelitian analitik dengan menggunakan cross sectional study. Variabel dalam penelitian diukur dan diamati dalam waktu yang bersamaan dalam waktu tertentu.

Penelitian dilaksanakan di Klinik "X" yang berada di Kota Surabaya.

Populasi yang digunakan adalah jumlah populasi kunjungan pasien pada Klinik "X" sepanjang tahun 2016. Penentuan jumlah sampel dengan metode simple random sampling, yaitu teknik pengambilan sampel dengan pengambilan sampel menggunakann secara bebas. Metode ini peneliti dapat mengambil orang yang ditemui sebagai sampel penelitian selama dapat memenuhi kriteria sampel penelitian.Jumlah sampel dari perhitungan sebesar 89 respoden.

Data akan dilakukan pengolahan menjadi dua tahapan, tahapan pertama dilakukan penghitungan secara desktiptif terhadap kepuasan dan penilaian terhadap perceived customer value. Penilaian kepuasan dihitung sebanyak empat kali, yaitu penghitungan kepuasan kualitas interaksi, kepuasan kualitas lingkungan fisik, dan kepuasan kualitas hasil. Tahapan kedua dilakukan analisis statistik menggunakan uji chi-square. Analisis tersebut dilakukan untuk mengetahui hubungan antara perceived customer value dengan kepuasan.

\section{HASIL DAN PEMBAHASAN}

Kepuasan Kualitas Interaksi

Tabel 1. Kepuasan Responden terhadap Kualitas Interaksi

\begin{tabular}{lrr}
\hline \multicolumn{1}{c}{ Kategori } & N & \multicolumn{1}{c}{$\%$} \\
\hline Tidak Puas & 4 & 4.5 \\
\hline Puas & 85 & 95.5 \\
\hline TOTAL & 89 & 100.0 \\
\hline
\end{tabular}

Pada Tabel 1. dapat diamati kepuasan kualitas interaksi (interaction quality) adalah pada kategori puas sebesar $95.5 \%$. Hal tersebut menjelaskan bahwa kualitas interaksi yang ada pada Klinik " $X$ " menurut responden adalah merasa puas. Kualitas interaksi tersebut meliputi aspek sikap (attitude), perilaku (behavior), dan keahlian (expertise).

Aspek sikap pada kualitas interaksi meliputi pemenuhan petugas, respon petugas dalam menanggapi keluhan, kepedualian petugas menanggapi keluhan, kesopanan petugas, dan keramahan petugas berdasarkan penilaian responden adalah pada kategori puas.

\section{Kepuasan Kualitas Lingkungan Fisik}

Tabel 2. Kepuasan Responden terhadap Kualitas Lingkungan Fisik

\begin{tabular}{lrr}
\hline \multicolumn{1}{c}{ Kategori } & N & \multicolumn{1}{c}{$\%$} \\
\hline Tidak Puas & 20 & 22.5 \\
\hline Puas & 69 & 77.5 \\
\hline TOTAL & 89 & 100.0 \\
\hline
\end{tabular}

Pada Tabel 2 diketahui kualitas lingkungan fisik (service environment quality) meliputi ambient condition, desain fasilitas, dan faktor sosial. Kepuasan responden terhadap kualitas lingkungan fisik adalah pada kategori puas sebesar $77.5 \%$ responden. Hal tersebut menjelaskan bahwa kualitas 
lingkungan fisik di Klinik " $X$ " menurut pelanggan adalah kategori puas.

\section{Kepuasan Kualitas Hasil}

Tabel 3. Kepuasan Responden terhadap Kualitas Hasil

\begin{tabular}{lrr}
\hline \multicolumn{1}{c}{ Kategori } & N & \multicolumn{1}{c}{$\%$} \\
\hline Tidak Puas & 7 & 7.9 \\
\hline Puas & 82 & 92.1 \\
\hline TOTAL & 89 & 100.0 \\
\hline
\end{tabular}

Pada Tabel 3. dapat diamati secara keseluruhan kepuasan responden terhadap kualitas hasil terkategori puas sebesar 92.1\%. Hal ini menggambarkan bahwa kepuasan terhadap kualitas hasil dari proses waktu tunggu, kebersihan ruangan, penampilan petugas, kebersihan dan perawatan peralatanm, serta pengalaman secara keseluruhan di Klinik "X" menurut responden adalah puas.

\section{Kepuasan Total}

Tabel 4. Kepuasan Total Responden

\begin{tabular}{lrr}
\hline \multicolumn{1}{c}{ Kategori } & N & \multicolumn{1}{c}{$\%$} \\
\hline Tidak Puas & 7 & 7.9 \\
\hline Puas & 82 & 92.1 \\
\hline TOTAL & 89 & 100.0 \\
\hline
\end{tabular}

Secara keseluruhan kepuasan total responden yang terdapat pada Tabel 4 terkategori puas sebesar 92.1\%. Hal ini menggambarkan bahwa kepuasan responden terhadap kualitas pelayaan meliputi kepuasan terhadap kualitas interaksi, kepuasan terhadap kualitas lingkungan fisik, dan kepuasan terhadap kualitas hasil menurut responden adalah puas. Sehingga disimpulkan bahwa, pasien Klinik "X" merasa puas dengan pelayanan yang diberikan.

Tabel 5. Persepsi Responden terhadap Aspek Customer Value

\begin{tabular}{lcccccccc}
\hline \multicolumn{1}{c}{ Nilai } & \multicolumn{2}{c}{ Sangat Kurang } & \multicolumn{2}{c}{ Kurang } & \multicolumn{2}{c}{ Baik } & \multicolumn{2}{c}{ Sangat Baik } \\
\cline { 2 - 10 } & $\mathbf{N}$ & $\%$ & $\mathbf{N}$ & $\%$ & $\mathbf{N}$ & $\%$ & $\mathbf{N}$ & $\%$ \\
\hline Pelayanan & 0 & 0 & 13 & 14.6 & 62 & 69.7 & 14 & 15.7 \\
\hline Kesesuaian premi yang dibayarkan & 1 & 1.1 & 14 & 15.7 & 60 & 67.4 & 14 & 15.7 \\
\hline Perasaan Positif & 1 & 1.1 & 12 & 13.5 & 69 & 77.5 & 7 & 7.9 \\
\hline Status Sosial & 0 & 0 & 7 & 7.9 & 76 & 85.4 & 6 & 6.7 \\
\hline Pengorbanan Waktu & 2 & 2.2 & 17 & 19.1 & 63 & 70.8 & 7 & 7.9 \\
\hline Kemanfaatan & 0 & 0 & 9 & 10.1 & 70 & 78.7 & 70 & 78.7 \\
\hline
\end{tabular}

Tabel 6. Perceived Customer Value

\begin{tabular}{lrr}
\hline \multicolumn{1}{c}{ Kategori } & N & $\%$ \\
\hline Kurang & 12 & 13.5 \\
\hline Baik & 77 & 86.5 \\
\hline TOTAL & 89 & 100.0 \\
\hline
\end{tabular}

\section{Perceived Customer Value}

Perceived customer value yang didapatkan oleh pasien Klinik "X" dapat dilihat pada Tabel 5. Aspek yang dinilai meliputi value terhadap pelayanan, kesesuaian premi yang dibayarkan dengan pelayanan yang diterima, perasaan positif yang timbul, status sosial yang didapatkan dengan menggunakan pelayanan di Klinik "X”, perngorbanan waktu, serta kemanfaatan yang dirasakan oleh pelanggan.

Pada Tabel 5 diketahui bahwa persepsi responden terhadap aspek customer value adalah baik diatas $60 \%$. Nilai baik tertinggi pada aspek status sosial dan nilai kurang tertinggi pada pengorbanan waktu. Hal ini menggambarkan bahwa value tertinggi yang didapatkan oleh pelanggan di Klinik "X" adalah pada status sosial. Pengorbanan 
waktu merupakan value yang kecil berdasarkan persepsi responden.

Secara keseluruhan perceived customer value responden terkategori baik yaitu sebesar $86.5 \%$ responden. Hal ini menggambarkan bahwa nilai pelanggan terhadap pelayanan, kesesuaian premi yang dibayarakan, perasaan positif yang timbul, status sosial, pengorbanan waktu, dan kemanfaatan di Klinik "X" menurut persepsi responden adalah baik.

\section{Hubungan antara kepuasan dengan Perceived Customer Value}

Untuk mengetahui hubungan antara kepuasan dengan perceived customer value, dilakukan uji chisquare yang dapat dilihat pada Tabel 7 .

Tabel 7. Hubungan Kepuasan dengan Perceived Customer Value

\begin{tabular}{|c|c|c|}
\hline $\begin{array}{c}\text { Aspek } \\
\text { kepuasan }\end{array}$ & value & $\begin{array}{c}\text { Asymp. Sig. (2- } \\
\text { sided) } \\
\text { (Likelihood } \\
\text { Ratio) }\end{array}$ \\
\hline $\begin{array}{l}\text { Kepuasan } \\
\text { Kualitas } \\
\text { Interaksi }\end{array}$ & 8.466 & 0,004 \\
\hline $\begin{array}{l}\text { Kepuasan } \\
\text { Kualitas } \\
\text { Lingkungan } \\
\text { Fisik }\end{array}$ & 2,601 & 0.107 \\
\hline $\begin{array}{l}\text { Kepuasan } \\
\text { Kualitas Hasil }\end{array}$ & 8.404 & 0,004 \\
\hline Kepuasan Total & 4.088 & 0.043 \\
\hline
\end{tabular}

Tabel 7 menunjukan bahwa kepuasaan kualitas interaksi pada responden memiliki signifikansi 0.04 $(\leq 0.05)$ yang berarti ada hubungan antara kepuasan pasien dalam hal kualitas interaksi di Klinik " $X$ " dengan perceived customer value tersebut.

Kualitas interaksi memiliki keterkaitan yang erat terhadap timbulnya value oleh pelanggan, hal ini dikarenakan dalam kualitas interaksi ada titik temu antara pemberi pelayanan kesehatan meliputi petugas administrasi, perawat, dan dokter dengan pengguna pelayanan kesehatan yaitu pasien pada Klinik "X". Interaksi yang baik dari petugas Klinik "X" memberikan pengaruh terhadap perceived customer value.

Sejalan dengan pendapat Kotler, et al. (2009), bahwa value yang tinggi didapatkan dari hubungan baik pemberi jasa dengan pengguna jasa, yaitu petugas pada Klinik " $X$ ” dan pengguna jasa.

Kepuasan kualitas lingkungan fisik (sig. 0,107) tidak menunjukan adanya hubungan yang signifikan dengan perceived customer value. Tidak adanya hubungan antara kepuasan lingkungan fisik menjelaskan bahwa aspek kualitas fisik memiliki pengaruh yang tidak signifikan terhadap pelayan kesehatan. Hal tersebut kemungkinan disebabkan karena faktor dari pelanggan itu sendiri. Pelanggan atau pengguna jasa pada Klinik "X", memiliki kemungkinan pendapat bahwa penyedia layanan jasa yang terpenting adalah bagaimana pelayanan serta hasil yang didapatkan. Dalam arti lain, faktor kualitas lingkungan fisik memiliki value yang bias berdasarkan persepsi pelanggan.

Kepuasaan kualitas hasil pada responden memiliki signifikansi $0.04(\leq 0.05)$ yang berarti ada hubungan antara kepuasan pasien dalam hal kualitas hasil terhadap perceived customer value. Kepuasan hasil dalam pelayanan kesehatan merupakan kepuasan yang dirasakan pada pelanggan seperti waktu tunggu dalam proses pelayanan.

Waktu tunggu dimulai dari pelanggan datang, melakukan pendaftaran, mendapatkan pelayan oleh dokter, dan pemberian obat oleh petugas dengan 
tujuan untuk mendapatkan kesembuhan. Hal tersebut memberikan gambaran yang jelas bahwa value dari pelanggan akan proses waktu tunggu memilik pengaruh yang berarti. Value ini merupakan pengorbanan waktu yang harus diberikan pelanggan dalam melakukan akses pelayanan kesehatan.

Pengalaman secara keseluruhan yang masuk dalam kepuasan terhadap kualitas hasil menjadi bagian dari penentu hubungan terhadap timbulnya perceived customer value.

Kepuasan total (sig. $0,043 \leq 0,05$ ) memiliki hubungan yang signifikan dengan perceived customer value. Kepuasan total yang didapatkan dari kepuasan kualitas interaksi, kepuasan kualitas lingkungan fisik, dan kepuasan kualitas hasil memiliki pengaruh terhadap perceived customer value. Hal ini menjelaskan bahwa perceived customer value memiliki hubungan terhadap kepuasan. Penelitian yang sama dilakukan oleh Oh, H. (1999), menjelaskan bahwa perceived customer value dipengaruhi oleh customer satisfaction. Selain itu adanya perceived customer value juga memiliki pengaruh terhadap terjadinya repurchase intention dan word of mouth. Kedua hal tersebut merupakan salah satu indikator loyalitas yang dimiliki pelanggan.

Repurchase intention sendiri memiliki makna bahwa pelanggan akan melakukan proses pembelian ulang dari suatu produk atau jasa yang telah digunakannya atas timbulanya value yang baik. Sedangakan word of mouth adalah penyampaian informasi dari pelanggan atas value yang didapatkan dari penyedia jasa, untuk mengajak orang lain atau orang terdekatnya untuk menggunakan produk atau jasa yang sejenis.
Penelitian dari Chen, C.F (2008) menjelaskan secara lebih komplek bahwa terdapat hubungan antara kualitas pelayanan, value, dan kepuasan.

\section{SIMPULAN}

Dari hasil penelitian dapat disimpulkan bahwa kepuasan terhadap kualitas interaksi masuk dalam kategori puas. Kepuasan terhadap kualitas lingkungan fisik masuk dalam kategori puas. Kepuasan terhadap kualitas hasil masuk dalam kategori puas.

Kepuasan secara total yaitu gabungan antara kepuasan kualitas interaksi, kepuasan kualitas lingkungan fisik, dan kepuasan kualitas hasil memiliki kategori yang sama yaitu puas.

Terdapat hubungan yang signifikan antara kepuasan kualitas interaksi terhadap perceived customer value. Tidak ada hubungan yang signifikan antara kepuasan kualitas lingkungan fisik terhadap perceived customer value. Terdapat hubungan yang signifikan antara kepuasan kualitas hasil terhadap perceived customer value. Secara keseluruhan dari penilaian kepuasan memiliki hubungan yang signifikan terhadap perceived customer value.

\section{DAFTAR PUSTAKA}

Chen, C.F., 2008. Investigating structural relationships between service quality, perceived value, satisfaction, and behavioral intentions for air passengers: Evidence from Taiwan. Transportation Research Part A, 42(4): 709-17.

Graf, A., and Maas, P., 2008. Customer value from a customer perspective: A comprehensive review. Journal für Betriebswirtschaft, 58(1), 120.

lqbal, M., 2012. Pengaruh Persepsi Nilai Harapan Dan Kepercayaan Terhadap Kepuasan Konsumen Penyedia Jasa Internet di Jabodetabek. Jurnal Kepuasan Konsumen, 16. 
Kotler, P., and Keller, K.L., 2009. Manajemen Pemasaran. Jakarta: Penerbit Erlangga

Lewis, R.C. and Booms, B.H., 1983. The marketing aspects of service quality. in Berry, L., Shostack, G. and Upah, G. (Eds), Emerging Perspectives on Services Marketing (pp. 99107.). Chicago, LL: American Marketing Association.

Nasution, M., 2005. Total Quality Management. Jakarta: Gramedia Pustaka Utama.

Oh, H. 1999. Service quality, customer satisfaction, and customer value: A holistic perspective. International Journal of Hospitality Management 18, 67-82

Brady, M.K., \& Cronin, J.J., 2001. Some new thoughts on conceptualizing perceived service quality: A hierarchical approach. Journal of Marketing, 65(3), 34-49.

Supriyanto, S., and Wulandari, R.D., 2011. Manajemen Mutu Pelayanan Kesehatan. Surabaya: Pohon Cahaya.

Tjiptono, Fandy. 2008. Sevice Management: Mewujudkan Layanan Prima.Yogyakarta: CV. ANDI

Tung, F.C., 2013. Customer Satisfaction, Perceived Value and Customer Loyalty: The Mobile Services Industry in China. African Journal of Business Management, 7(18), 1730-1737.

Wijaya, Tony. 2011. Manajemen Kualitas Jasa. Jakarta: PT. Indeks.

Yamit, Z., 2005. Manajemen Kualitas Produk \& Jasa. Yogyakarta: Ekonesia. 